\title{
Legal Framework for Pontocaspian Biodiversity Conservation in the Danube Delta (Romania and Ukraine)
}

\author{
Aleksandre Gogaladze ${ }^{1,2 *}$, Jacobus C. Biesmeijer ${ }^{2,3}$, Mikhail O. Son ${ }^{4}$, \\ Oleksii Marushchak ${ }^{5}$, Frank P. Wesselingh ${ }^{1,6}$, Matteo Lattuada ${ }^{7,8}$, Cristina Sandu ${ }^{9}$, \\ Christian Albrecht ${ }^{8}$, Simona Mihailescu ${ }^{10}$ and Niels Raes ${ }^{1,11}$

\begin{abstract}
${ }^{1}$ Marine Biodiversity Department, Naturalis Biodiversity Center, Leiden, Netherlands, ${ }^{2}$ Department of Environmental Biology, Institute of Environmental Sciences, Leiden University, Leiden, Netherlands, ${ }^{3} \mathrm{NL}$ Biodiversity and Society, Leiden, Netherlands, ${ }^{4}$ Department of Quality of Aquatic Environment, Institute of Marine Biology, National Academy of Sciences of Ukraine, Odessa, Ukraine, ${ }^{5}$ Department of Animal Monitoring and Conservation, I.I. Schmalhausen Institute of Zoology of National Academy of Sciences of Ukraine, Kiev, Ukraine, ${ }^{6}$ Department of Earth Sciences, Utrecht University, Utrecht, Netherlands, ${ }^{7}$ Department Landscape Ecology and Environmental Systems Analysis, Institute of Geoecology, Technische Universität Braunschweig, Braunschweig, Germany, ${ }^{8}$ Department of Animal Ecology and Systematics, Justus Liebig University Giessen, Giessen, Germany, ${ }^{9}$ International Association for Danube Research, Vienna, Austria, ${ }^{10}$ Department of Ecology, Taxonomy and Nature Conservation, Institute of Biology Bucharest, Romanian Academy, Bucharest, Romania,

${ }^{11}$ Netherlands Biodiversity Information Facility, Leiden, Netherlands
\end{abstract}

\section{OPEN ACCESS}

Edited by:

Mohammad Farhadinia, University of Oxford, United Kingdom

Reviewed by:

Mauro Fois,

University of Cagliari, Italy

Nicola J. Van Wilgen,

South African National Parks,

South Africa

*Correspondence:

Aleksandre Gogaladze aaleksandre.g@gmail.com

Specialty section:

This article was submitted to

Animal Conservation,

a section of the journal

Frontiers in Conservation Science

Received: 14 November 2021 Accepted: 07 January 2022

Published: 02 February 2022

Citation:

Gogaladze A, Biesmeijer JC, Son MO

Marushchak $O$, Wesselingh FP,

Lattuada M, Sandu C, Albrecht C, Mihailescu S and Raes N (2022) Legal

Framework for Pontocaspian

Biodiversity Conservation in the

Danube Delta (Romania and Ukraine).

Front. Conserv. Sci. 3:814781.

doi: 10.3389/fcosc.2022.814781
The declining biodiversity has upsetting consequences for social and economic development and represents a major concern for humanity. Legal and political framework plays an important role in biodiversity conservation planning, implementation, and coordination of actions. Legal provisions are complex and operate on different levels of governance (from supranational to national), which means that the status of single species or populations may be governed by a set of interacting or even conflicting regulations, with increasing complexity for species that occur across national borders. Romania (EU member state) and Ukraine (non-EU member state) exemplify neighboring countries with different governance systems, which share the same endemic aquatic communities inhabiting the transitional zones between freshwater and marine ecosystems, known regionally as Pontocaspian (PC) biota. These communities include flagship species such as sturgeons and less-known crustaceans and mollusks and are severely threatened as a result of human activities. We assessed the legal basis for the protection of PC biota in the Danube Delta and the effectiveness of current conservation approaches based on a review of legal documents and literature, expert opinion, and practitioner reflections regarding PC biodiversity conservation. We found that PC invertebrate species are not adequately addressed in the current legal documents and that the surrogate approach (where protection of umbrella species results in protection of background species) does not work as there is little overlap between the habitats of sturgeons and PC invertebrate communities. Furthermore, the habitat definitions currently used in legal documents lack the level of detail needed to protect PC habitats that are characterized by specific salinity (brackish) conditions. We finish by sketching out recommendations toward improved legal and political frameworks for effective and efficient conservation of PC invertebrate biota.

Keywords: biodiversity, conservation, governance, legal arrangements, Pontocaspian region, environmental policy, Romania, Ukraine 


\section{INTRODUCTION}

The dramatic decline of biodiversity received an increasing recognition in recent years as one of the major issues faced by the humanity (OECD, 2019; World Economic Forum, 2020). For the first time, the assessment conducted by the World Economic Forum (2020) highlighted the impact of "biodiversity loss" as one of the top five global risks to social and economic development. In complex socio-ecological systems extending across national borders, the management, and conservation of species and habitats is particularly challenging, as numerous socio-political and environmental factors should be harmonized (López-Hoffman et al., 2010; Dallimer and Strange, 2015; Kark et al., 2015).

Effective conservation of biodiversity requires a clear and transparent legal and political framework (De Klemm and Shine, 1993; Díaz et al., 2019). International Environmental Regimes (IERs) set conservation goals and provide guidance on how to achieve these goals, whereas the national legislation provides a framework for the actions and restrictions at the national level to meet international obligations. A prominent example of an IER is the Convention on Biological Diversity (CBD, 1992), which defines the global biodiversity goals and provides the policies for its contracting parties to implement. The European Union (EU), while establishing the environmental policy for its member states (see e.g., Delreux and Happaerts, 2016), is conceptually broader than an IER (Skjærseth and Wettestad, 2002), because "EU member states have transferred national sovereignty to a supranational institution. Accordingly, EU laws are directly binding on the member states rather than requiring member states to ratify joint commitments, as is the case within international regimes" (Skjærseth and Wettestad, 2002, p. 103).

Legal arrangements to address biodiversity conservation operate on different levels of governance from supranational (e.g., $\mathrm{UN}$ or EU) to national and sub-national. This means that rules and policies inevitably influence each other, whether they target the same or different environmental challenges (VisserenHamakers, 2018). As a result, often the same species and single populations are governed by an interacting, combined set of regulations, more so if their distribution crosses national borders (Singh, 1999; Iwanski, 2011). Regulations may support each other, have no effect, or may counteract. Few studies have investigated the relationships and the combined performance of different rules and governance systems in the context of biodiversity conservation (Gomar et al., 2014; VisserenHamakers, 2018). However, understanding the mutual effects of different legal instruments and how these instruments deal jointly with conservation needs, is imperative for effective conservation outcomes (Visseren-Hamakers, 2015). In this paper, we assess the level of coherence among the regulations governing biodiversity conservation in the Danube Delta, the second largest European delta (after Volga Delta), located in Romania (80\%) and Ukraine $(20 \%)$, that hosts unique aquatic fauna.

Romania and Ukraine exemplify countries with different governance systems, which share the responsibility for effective conservation and governance of species and habitats within the Danube Delta (ICPDR, 2015, 2018, 2021). Romania is an EU member state since 2007, while Ukraine is signatory to an EU-association agreement. Consequently, Romania is legally bound to EU Directives, including the Habitats Directive (EU, 1992) and Birds Directive (EU, 2009), respecting at the same time the national conservation legislation, while Ukraine is currently in the process of adapting its legislation to the EU acquis. The Danube Delta is internationally recognized as EU's largest wetland and important wildlife habitat and its management is ensured by a series of different regulations (The World Bank Study Team, 2014; Baboianu, 2016; Teampau, 2020). For example, as a "Waterfowl Habitat" it is a designated Ramsar site in Romania and Ukraine. Additionally, within the UNESCO Man and Biosphere Program, it is declared as a "transboundary Biosphere Reserve shared by Romania and Ukraine." Furthermore, the Danube Delta is protected and managed through a series of European conventions and directives, such as the Danube River Protection Convention (Council of Europe, 1979; DRPC, 1994), the Water Framework Directive (2000/60/EC), the Habitats Directive (92/43/EEC), and the Birds Directive (2009/147/EC), among others. The Danube Delta encompasses a network of protected areas (PAs) established under Natura 2000 and Emerald networks in Romania and Ukraine, respectively, providing protection to threatened species and habitats (Díaz, 2010; Evans, 2012).

The Danube Delta shelters a unique, aquatic ecological community, known as the Pontocaspian (PC) biodiversity (Popa et al., 2009; van de Velde et al., 2019; Wesselingh et al., 2019), which is characterized by charismatic vertebrate species such as sturgeons, less-known invertebrate groups, such as mollusks and crustaceans, as well as diatoms and dinoflagellates (Grigorovich et al., 2003; Marret et al., 2004). Pontocaspian habitats comprise transitional zones between the freshwater and salt water bodies on coastal plains of the Black Sea and the Sea of Azov, such as lower stretches of rivers, lagoons, delta areas, estuaries, brackish lakes, and bays, as well as the entire Caspian Sea (Zenkevitch, 1963; Gogaladze et al., 2021). However, many PC species also inhabit fresh waters in lower reaches of large rivers. Pontocaspian biota is threatened and rapidly declining due to direct anthropogenic drivers, such as damming of rivers, modification of marine and freshwater influx in coastal areas, and invasive species among others (Son, 2007a,b; van de Velde et al., 2019; Gogaladze et al., 2021), as well as indirect drivers, such as limited knowledge on PC species and suboptimal institutional cooperation of stakeholders (Wesselingh et al., 2019; Gogaladze et al., 2020a,b). The legal basis to address the decline of PC biodiversity has not been studied, with the exception of sturgeon species (Reinartz et al., 2012; Munteanu et al., 2013).

Conservation of species can be achieved through ecosystembased measures (also known as the coarse-filter approach) and/or species-based measures (also known as fine-filter approaches) (Glowka et al., 1998). Ecosystem-based conservation targets biotic communities, instead of individual species and potentially benefits many species simultaneously. Biotic communities are often defined by surrogate taxa (Groves et al., 2000), which involve keystone, indicator, umbrella, and flagship species (Favreau et al., 2006). Flagship species are primarily used to promote public awareness and to raise funds for conservation 
(Verissimo et al., 2011), while the protection of umbrella species is expected to benefit a wide range of co-occurring species (Roberge and Angelstam, 2004; Caro, 2010). Consequently, the flagship species selection is based on sociocultural considerations, whereas umbrella species are selected based on ecological criteria (Caro, 2010; Verissimo et al., 2011). The sturgeon species are both flagship and umbrella species of the Black Sea and Danube Delta region according to the International Commission for the Protection of the Danube River (ICPDR, 2018). Whether sturgeons can be seen as surrogates for the other PC biota remains unclear. For example, studies on benefits to the invertebrate PC communities from sturgeon conservation are lacking. This may be, partly, explained by the fact that PC invertebrate species have disputed taxonomy, include multiple synonymies and misidentifications, and are mostly data deficient in IUCN assessments (see e.g., Wesselingh et al., 2019 for PC mollusk species). Consequently, it might be the case that PC invertebrate species fall through the "coarse filters" of area-based conservation approaches (and thus do not benefit from sturgeon conservation measures) and may require the "fine-filter" of species or community-based approaches.

We use the Danube Delta case to assess whether the legal bases in Romania and Ukraine are sufficient to support the conservation of PC invertebrate biota and to study the impact of regulations from the supranational institutions, such as the EU. First, we analyze whether PC invertebrate species or their habitats are represented in the current legal documents. Second, we assess whether the relevant regulations are coherent among each other and whether the conservation of PC flagship species is likely to benefit the "background" PC species and their habitats. Following Gomar et al. (2014), we define coherence as the complementarity of action (mutual reinforcement) and not as post-accession compliance with EU environmental legislation, or consistency or compatibility of action (absence of contradiction). Third, we assess the degree to which the conservation of PC invertebrate species and habitats is implemented, through examining the current conservation programs and plans and the extent to which PC habitats are covered by the network of PAs as well as the representation of PC species in the PA management plans. Sturgeon species are not a target of this work and we consider them in a limited way as a group whose conservation can benefit the conservation of PC invertebrate species (Gogaladze et al., 2020a,b).

\section{METHODS}

Pontocaspian habitats encompass several habitats from the European Nature Information System (EUNIS) classification (https://eunis.eea.europa.eu/). These are:

A2: Littoral sediment

C1.2: Permanent mesotrophic lakes, ponds and pools

C2.32: Metapotamal and hypopotamal streams

C2.41: Brackish water tidal rivers

C2.42: Freshwater tidal rivers (within low reaches of large rivers and estuaries in Ukrainian and Romanian sectors of Black and Azov seas)

\section{X01: Estuaries}

X03: Brackish coastal lagoons

In the Danube Delta (Figure 1) all except "C2.41: Brackish water tidal rivers" are present, so we excluded this habitat from the analysis. There are no tides in the Black Sea Basin (Giosan et al., 1999), but the regular wind surges that occur in the open estuaries, e.g., in the Danube and Don Deltas, cause the upstream movement of the sea water into the deltas creating conditions that are similar to the "tidal rivers" in other sea basins. Therefore, we included the C2.42: Freshwater tidal rivers in our analysis. We adopted the boundaries of the Danube Delta area from WWF (2007) and The World Bank Study Team (2014, 2015), who include the lower stretch of the Danube River-from Braila to the Black Sea; its three branches-Chilia, Sulina, and Sf. Gheorghe and the floodplain lakes around these branches; Razim-Sinoe Lake complex in Romania to the south and a number of large lakes on the Ukrainian northern side of the delta (Figure 1).

\section{Identification of Relevant Legal Documents}

We define PC biodiversity related legal documents as those which directly promote the conservation of PC species and/or PC habitats. Legal documents for the analysis were selected on global, regional (EU and the Black Sea), and national levels. At the global level, five biodiversity-related conventions are relevant (Koester, 2002) and were considered in this study: (1) Convention on Biological Diversity (CBD, 1992); (2) Convention on the International Trade in Endangered Species of Wild Fauna and Flora (CITES, 1973), also known as the Washington Convention; (3) Convention on the Conservation of Migratory Species of Wild Animals (CMS, 1979), also known as the Bonn Convention; (4) Convention on Wetlands of International Importance Especially as Waterfowl Habitat (UNESCO, 1971), also known as the Ramsar Convention; and (5) Convention for the Protection of the World Cultural and Natural Heritage (UNESCO, 1972), commonly known and World Heritage Convention (WHC). In addition, the Convention on Environmental Impact Assessment in a Transboundary Context, also known as Espoo Convention (UNECE, 1991) was also considered.

At the regional level (EU and the Black Sea), conventions were selected based on two criteria: (1) those that listed the species, ecological communities, and habitat types, or any of these as a cornerstone for conservation efforts and (2) those that were operational in Ukraine and/or in Romania. Most prominent example of such convention is the Bern Convention on the Conservation of European Wildlife and Natural Habitats (Council of Europe, 1979). Additionally, we considered Convention on the Protection of the Black Sea against Pollution (Black Sea Commission, 1992), also known as "Bucharest Convention," which did not directly list the species and habitat types but whose implementation required listing of species and habitats on national and/or regional levels. Furthermore, the Convention on cooperation for the protection and sustainable use of the river Danube (DRPC, 1994) was included in the analysis. At the EU level, all biodiversity-related Directives, such as: (1) The Birds Directive (EU, 2009); (2) the Habitats Directive (EU, 1992); (3) Water Framework Directive 


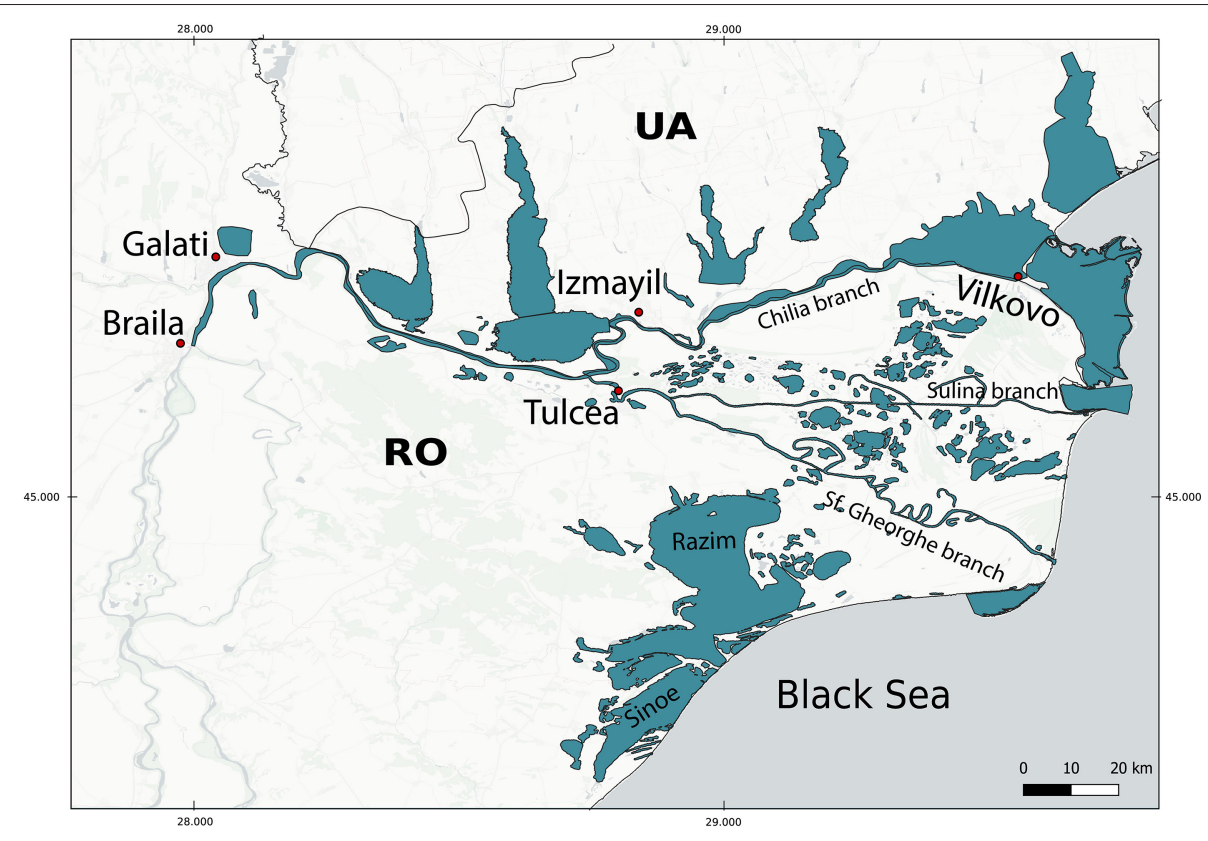

FIGURE 1 | Pontocaspian habitats in the Danube Delta are shown in blue. According to Gogaladze et al. (2021) PC habitats extend upstream the Danube River from Braila up to Gura Vaii commune in Romania. This study, however, focuses on Danube Delta, hence the Danube sector upstream from Braila is not included in the analysis.

(EU, 2000); and (4) Marine Strategy Framework Directive (EU, 2008) were included. In addition, the EU Wildlife Trade Regulations (EU, 1996), which is the EU-level implementation mechanism of CITES and the pan-European Sturgeon Action Plan, adopted in the frame of the Council of Europe (2018) were also included.

National Romanian laws were retrieved from the national strategy and action plan of Romania for biodiversity conservation 2014-2020 (The Government of Romania, 2014) and the fifth national report to the $\mathrm{CBD}$ (Ministry of Environment Climate Change of Romania, 2014). The list of Ukrainian national laws was built from the fifth and sixth national reports on implementation of the CBD (Ministry of Ecology Natural Resources of Ukraine, 2015, 2018). The official texts of national laws and their amendments, appendices, and annexes were downloaded from the official legislative portals of Romania (http://legislatie.just.ro/) and Ukraine (https://zakon.rada.gov. ua/laws/main/index). Provisions of national laws were only available in official languages of the issuing countries so they were translated in English with the help of Google Translate for the analysis. All the legal documents and their amendments were carefully examined and only those were selected which (a) provided lists of species and/or habitats; and/or (b) which did not list species and/or habitats in their provisions but regulated public relations with regard to the listed species and habitats from the provisions of other laws.

Additionally, we examined the IUCN Red Lists of species and habitats at EU level. For PC species presence, we analyzed the "Red List of Non-Marine Mollusks" (Cuttelod et al., 2011) and the European Red List of Freshwater Fishes
(Freyhof and Brooks, 2011). It should be noted that the former was restricted to land and freshwater species of mollusks from a specified geographic region, therefore, brackish water species which were not listed on Fauna Europea web-site (http://www. faunaeur.org), were omitted from the project by IUCN For PC habitat representation in IUCN assessments we examined the European red list of habitats, part 1: marine habitats (Gubbay et al., 2016) and European red list of habitats, part 2: terrestrial and freshwater habitats (Janssen et al., 2016).

\section{Analysis}

We applied a mix of quantitative and qualitative research approaches and methods to analyze the identified legal documents (Landman, 2002). Quantitatively, we assessed firstly the extent to which the identified legal documents mention PC species and habitats in their formulations, using key word search (see Supplementary Material) and secondly, the degree to which PC habitats are covered by the existing network of PAs (see below). Qualitatively, we thoroughly read all the identified legal documents to understand the PC biodiversity conservation context and framing (see below).

\section{Quantitative Analysis}

To search for presence of PC species names in legal documents, we used all the recorded genus names known from the Danube Delta, within each PC group (see below), as search terms and checked all the identified legal documents for presence of these terms (Supplementary Table 1) using CRAN R Packages “pdftools” (Jeroen, 2021), "pdfsearch” (Brandon, 2018), "tidyverse" (Wickham et al., 2019), "textreadr" (Rinker, 2021). 
We accounted for taxonomic synonymy and misidentification by selecting both currently accepted and synonymous genus names, which have been used by different authors in the last decade. In total we retrieved 70 invertebrate genus names belonging to mollusks-gastropods and bivalves (Wesselingh et al., 2019); crustaceans-amphipods, cumaceans, copepods (Monchenko, 2003) and decapods (Policar et al., 2018); mysidae (Audzijonyte et al., 2008); cnidaria and hirudinea (Mordukhay-Boltovskoy, 1960). Finally, we also checked the two genus names of sturgeons (Acipenser and Huso).

Spatial data on Important Bird Areas was retrieved from Birdlife Data Zone, (http://datazone.birdlife.org/site/search) and the Ramsar dataset from the Ramsar website (https:// rsis.ramsar.org/). Data on Emerald network and Natura 2000 datasets were retrieved from the European Environment Agency (EEA, http://emerald.eea.europa.eu/ and https:// natura2000.eea.europa.eu/, respectively). Spatial data on national PAs was retrieved from IUCN World Database on Protected Areas (WDPA, https://www.iucn.org/theme/ protected-areas/our-work/world-database-protected-areas).

Data on PC habitats were retrieved from earlier work that defined, documented and mapped these habitats based on literature review and expert opinions (Gogaladze et al., 2021). We calculated the area of PC habitats and the percentage covered by PAs with a geometric overlying between the PC habitats and the PA polygons using QGIS 3.10 A Coruña. For each habitat polygon, we calculated the surface area and percentage covered by the PAs on three administrative levels: global (UNESCO, Ramsar Convention and Important Bird Areas), European (Natura 2000 network for Romania and Emerald network for Ukraine) and national (all types of national PAs).

\section{Qualitative Analysis}

Provisions of identified legal documents (Figure 2; Supplementary Tables 2, 3) were further read to understand how PC species and habitats were defined in the global, European and national legal documents and to examine whether PC biodiversity decline was addressed and how conservation measures and restrictions were framed. Additionally, we searched for and read the management plans of national PAs, Natura 2000 and Emerald Network sites that covered the PC habitats to examine whether PC biodiversity was adequately addressed in the management plans.

\section{RESULTS}

\section{Legal Landscape for Pontocaspian Biodiversity Conservation}

We identified a complex legal and political framework within which PC biodiversity conservation is embedded (Figure 2). For readability, we provide a full list and description of legal documents on global, regional and national levels, as well as their abbreviations in Supplementary Table 2.

\section{Species-Based Conservation}

Pontocaspian species were poorly represented in legal documents at all levels (Figure 3; Supplementary Table 4). The Appendices of CITES and the Bern Convention did not list any PC invertebrate species. On EU level, Habitats Directive included only one invertebrate PC species, namely a gastropod species Theodoxus danubialis (listed as Theodoxus prevostianus, which is an unaccepted term in need of an update to Theodoxus danubialis see Supplementary Table 4). All six Danube sturgeon species were listed in EU Habitats Directive (Supplementary Table 5). The MSFD listed the priority habitats and taxonomic groups, which encompassed benthic and pelagic habitats and habitats of special regional interest. Listed taxa included marine planktonic groups, benthic invertebrates, fishes, marine mammals, and reptiles among others. Pontocaspian groups, however, were not listed in MSFD.

We identified 12 Romanian national legislative documents and 14 Ukrainian legislative documents that listed species and/or habitats, or regulated public relations with regard to the species and habitats listed in the provisions of other laws (Figure 2; Supplementary Table 3). National legal documents of Romania and Ukraine listed all six Danube sturgeon species. As for the PC invertebrate species, Annex 4B on species of national interest of the Romanian Government Emergency Order no. 57/2007 listed all three limnocardiine bivalve species and one PC gastropod species (Figure 3; Supplementary Table 4). Other PC groups, however, were absent from Romanian national laws. The Red Data Book of Ukraine (RDBU), regulated by the Law No. 3055III, listed 13 invertebrate species from all PC groups except for decapods.

European regional IUCN species assessments relevant to PC biodiversity were conducted for fish and mollusk species only. For other PC invertebrate species IUCN assessments were lacking. All but one species of sturgeon were listed as critically endangered and the rest as vulnerable in IUCN assessments (see Supplementary Table 5). As for PC mollusks, one gastropod species was listed as vulnerable, two gastropod species were data deficient and four gastropod species were listed as least concern (Figure 3; Supplementary Table 4). Furthermore, the bivalve subfamily Lymnocardiinae (and the Cardiidae family to which it belongs) was completely absent. The Black Sea Red Data Book (BSRDB), which was created in response to the regional Bucharest Convention (Dumont et al., 1999), automatically included all species that were at that time listed in RDBU and Romanian laws and supplemented those with two additional amphipod species, such as Echinogammarus trichiatus Martynov, 1932 (as Chaetogammarus ischnus major) and Dikerogammarus villosus (Sowinskii, 1894).

\section{Area-Based Conservation}

Important PC habitats such as the estuarine habitats of nontidal seas (X01) and brackish coastal lagoons (X03) were poorly classified in the EUNIS habitat classification and absent as separate codes in Annex I of Resolution 4 (1996) of the Bern Convention and Annex I of Habitats Directive (Table 1; present only as complexes without distinction between littoral, benthic, and pelagic zones). Regional varieties of PC habitats in freshened 




FIGURE 2 | Pontocaspian biodiversity conservation policy landscape. International Environmental Regimes (IERs) set the conservation goals and guidance on how to achieve these goals, which then shape EU policy. National legislation provides the framework for actions and restrictions at national level to meet the international obligations. See a full list and description of legal documents, as well as abbreviation definitions in Supplementary Tables $\mathbf{2}, \mathbf{3}$.

parts of the Black Sea and branches of the Danube Delta were used neither by the Bern Convention nor by the EU Habitats Directive to structure the Natura 2000 and Emerald networks. Instead, higher level broad habitat types were used. For example, specific habitat in the Danube Delta such as "A5.224 Pontic mobile sands of the Danube mouths" was represented by a higher level "A5 Sublittoral sediment" habitat type. This higher-level habitat type failed to account for sublittoral sand in specific, variable salinity (estuarine) conditions (EUNIS habitat type A5.22). Furthermore, "C1.2 Permanent mesotrophic lakes, ponds, and pools," "C2.32 Metapotamal and hypopotamal streams" and "C2.42 Freshwater tidal rivers" were missing from the Annex I of Resolution 4 (1996) of the Bern Convention and Annex I of the Habitats Directive (Table 1). Within "C1.2 Permanent mesotrophic lakes, ponds and pools" several types of vegetation (e.g., "C1.222 Floating Hydrocharis morsus-ranae rafts" among others, see Table 1) are included in Annex I of Resolution 4 (1996) of the Bern Convention. However, these habitats are not valuable for most of the PC communities (see Table 1), as they are characterized by thickets of aquatic vegetation that lead to oxygen depletion in winter and the formation of thick layer of detritus and black silt at the bottom (Mordukhay-Boltovskoy, 1960). UNESCO (1971), did not list habitats or species that need protection, but on the Ninth Meeting of the Conference of the Parties (COP) Resolution IX.1 Annex E identified coastal tidal flats, rivers and streams, which form part of the PC habitats, as priority areas that shall receive more attention to improve integrated wetland inventory, assessment and monitoring. Pontocaspian habitats were poorly represented in IUCN assessments (Table 1).

Most of the PC habitats in the Danube Delta were covered by the sites of international importance, such as IBAs, Danube Delta Biosphere Reserve, Ramsar sites, World Heritage Sites, and Biosphere Reserves (Table 2; Figure 4). At the European level, Natura 2000 sites and Emerald Network provided almost an absolute coverage of the PC habitats (Table 2). National PAs partially covered the stretches of Danube River and few PC lakes in Romania and Ukraine, but ignored most of the important estuaries, which contain important PC invertebrate communities. In Ukraine, management plans were not in place for most of the PAs, while in Romania the conservation measures were included in the Management Plans approved in 2015 (see Supplementary Table 6). In the management plans that were in place, PC invertebrate species were not mentioned, placing no restrictions on interventions that endanger them. Management plans were non-existent for Emerald Sites in Ukraine which 


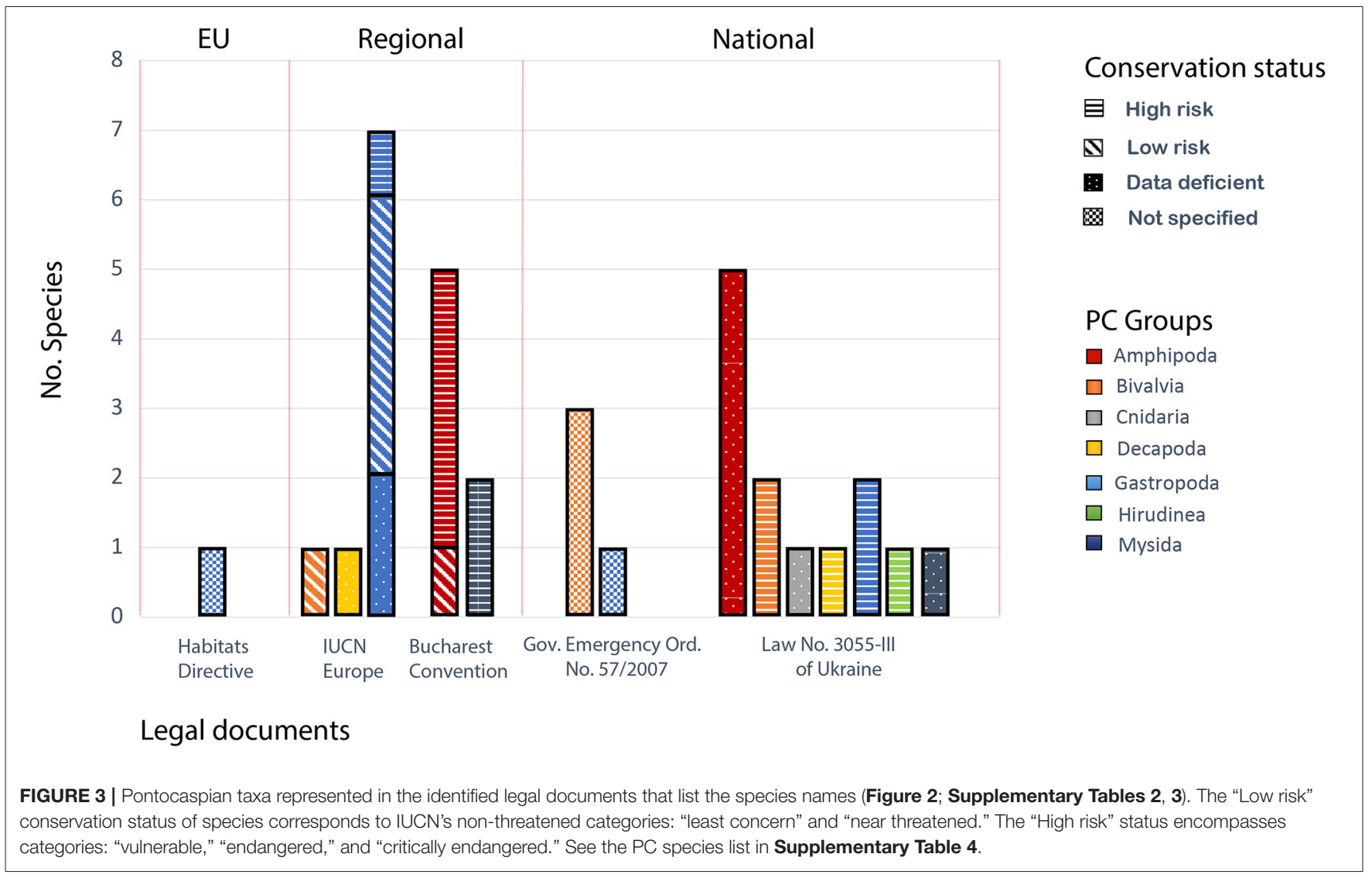

encompassed PC habitats, because the Law "On the Territories of the Emerald Network" of Ukraine was not yet into force.

Relevant Romanian and Ukrainian national legislations were not coherent (mutually reinforcing): neither vertically, i.e., coherent with global treaties and the EU directives, nor horizontally, i.e., coherent with each other. Reviewed reports and legal documents suggested that even though the national Romanian biodiversity legislation was in line with the provisions of $\mathrm{CBD}$, most of the strategies and action plans for biodiversity conservation were not implemented, because they were not adopted by normative acts and therefore had no legal power for enforcement (The Government of Romania, 2014). Furthermore, Romania faced considerable administrative, governance, and financial challenges in the implementation of EU Nature Directives (European Commission, 2019). In general, biodiversity conservation-related Romanian legislation was characterized by frequent amendments due to compliance to the EU Directives, resulting in a very complex landscape of conservation laws, secondary laws and emergency amendments to the laws (Supplementary Table 3). According to the fifth National Biodiversity Strategy and Action Plan (NBSAP) of Romania, the frequent emergency amendments resulted in a situation in which, "a series of sanctions are omitted for the non-compliance with some legal provisions already established (The Government of Romania, 2014, p. 39)." Biodiversity conservation related Ukrainian laws lacked the adequate subordinate legislation (regulations and guidelines). As part of European integration, many new Emerald sites were identified for designation and the Ukrainian law on the Territories of the Emerald Network was released for public consultations by the Ministry of Ecology Natural Resources of Ukraine (2018). However, as the law did not enter into force, the management plans for Emerald sites are currently lacking, precluding coherence in the implementation of the Natura 2000/Emerald site protection in Romania and Ukraine, respectively. Additionally, a previous study on the organizational network of stakeholders involved in PC biodiversity conservation in Ukraine identified incoherence within the Ukrainian environmental legislation due to some contradictory national laws, which complicated PC biodiversity conservation planning (Gogaladze et al., 2020b).

Sturgeons were well-protected by law as were their habitats. However, PC habitat range was larger (Figure 1) than the sturgeon habitats which comprise only the Danube River and its three branches (Schmutz and Sendzimir, 2018), therefore a large part of the PC habitats fell outside the regulatory scope of sturgeon related legislation. Whether the co-occurring part of the PC invertebrate biodiversity benefited from sturgeon related laws was unclear. Before 2006, sturgeon related legislation provided protection to sturgeons by prohibiting the use of certain types of fishing gear, regulating and limiting the number of fishing gears, craft and the power of vessels (e.g., Romanian Law. No. 192/2001 and Ukrainian Law No. 3677 in Supplementary Table 3). After 
TABLE 1 | Pontocaspian habitat coverage by legal documents.

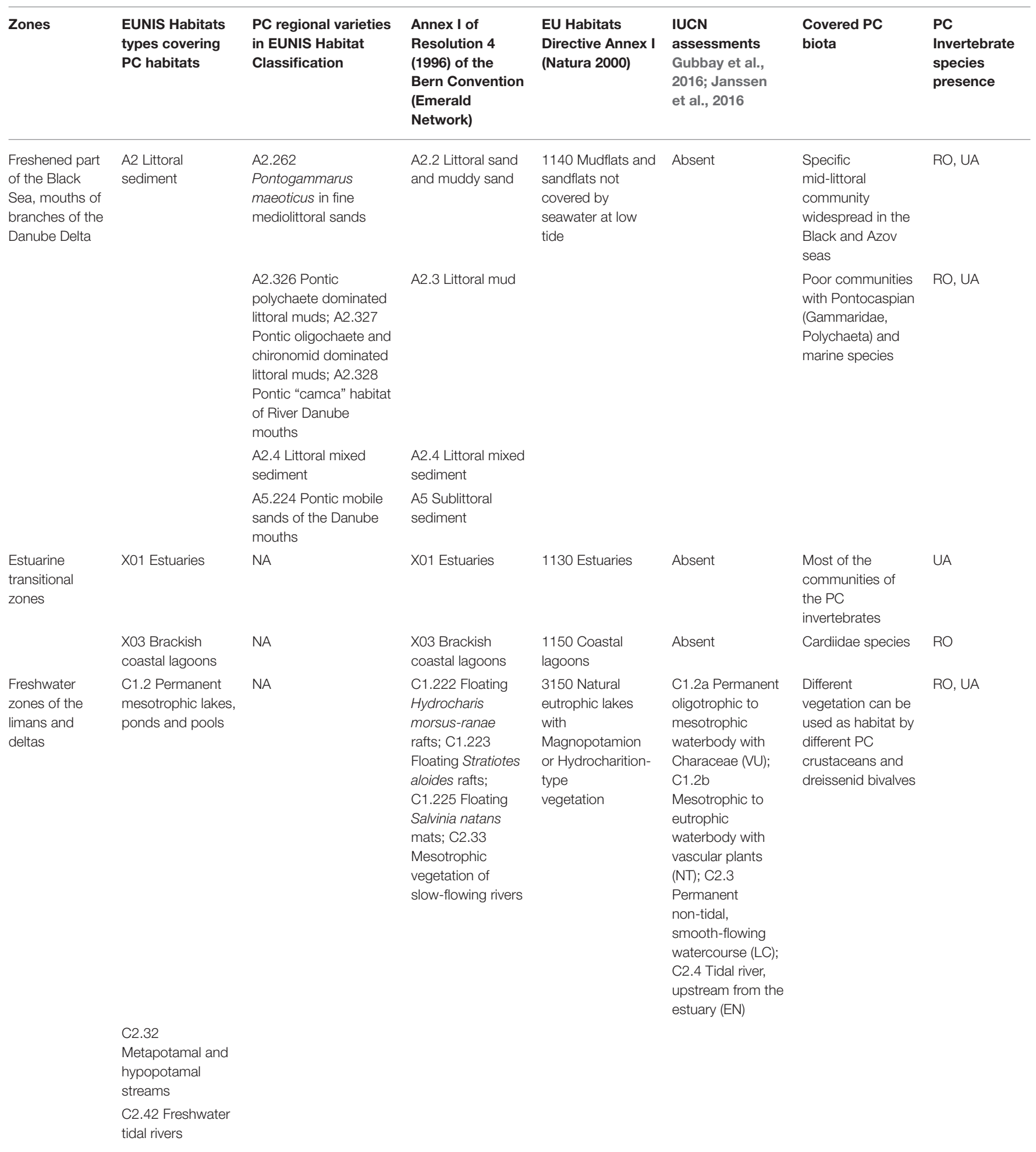

2006, a sturgeon fishery ban was declared in Romania, restocking programs were started and discussions to restore migration at the Iron Gates dams were launched at international level, as part of the conservation measures. Since then, sturgeon-related laws regulated the restocking of sturgeon species in Romania and Ukraine (e.g., Order No. 84/2012 of Romania and Law No. 5293VI of Ukraine). Dam constructions have been identified as one of the major threats to PC biodiversity (Gogaladze et al., 2021), 
TABLE 2 | Coverage of PC habitats by the network of protected areas across different administrative levels.

\begin{tabular}{|c|c|c|c|}
\hline Protection type & Romania & Ukraine & $\begin{array}{l}\text { Governance } \\
\text { level }\end{array}$ \\
\hline $\begin{array}{l}\text { UNESCO Man and } \\
\text { Biosphere } \\
\text { Programme }\end{array}$ & $75 \%$ & $29 \%$ & Global \\
\hline $\begin{array}{l}\text { World heritage } \\
\text { Sites }\end{array}$ & $75 \%$ & $\mathrm{~N} / \mathrm{A}$ & Global \\
\hline Ramsar sites & $99 \%$ & $45 \%$ & Global \\
\hline IBA & $96 \%$ & $41 \%$ & Global \\
\hline $\begin{array}{l}\text { Natura } 2000(\mathrm{HD} \text {, } \\
\text { SCl) }\end{array}$ & $95 \%$ & $\mathrm{~N} / \mathrm{A}$ & Regional/EU \\
\hline $\begin{array}{l}\text { Natura } 2000 \text { (BD, } \\
\text { SPA) }\end{array}$ & $99 \%$ & $\mathrm{~N} / \mathrm{A}$ & Regional/EU \\
\hline Emerald sites & $\mathrm{N} / \mathrm{A}$ & $96 \%$ & Regional/EU \\
\hline $\begin{array}{l}\text { National protected } \\
\text { areas }\end{array}$ & $7 \%$ & $32 \%$ & National \\
\hline
\end{tabular}

Values are the percentages of $P C$ habitats that are within protected areas. The $\mathrm{HD}, S \mathrm{Cl}$ stands for Habitats Directive, Site of Community Importance and BD, SPA stands for Birds Directive, Special Protection Area (see Supplementary Table 6 for details).

therefore dam removal and restoration of migration corridors is expected to have positive impact on the PC sturgeons as well as the invertebrate fauna.

\section{DISCUSSION}

Pontocaspian biodiversity conservation is embedded within a complex legal and political framework (Figure 2). Some of the PC species and parts of their habitats are included in the identified legal documents on global, regional, and national levels, however, the majority of the PC invertebrate species and the specific conditions of the brackish PC habitats, such as the salinity gradients, are not adequately addressed and defined. This results in the omission of PC invertebrate species from conservation management plans and implementation, as well as the environmental impact assessment studies, leading to suboptimal conservation actions. Furthermore, there is a lack of legal coherence across relevant Ukrainian and Romanian legislations and across the PC species groups covered by different legal documents, hindering effective conservation planning.

Worldwide, many species and ecosystems are separately managed between neighboring countries via domestic legal orders, despite the international agreements that are in place, precluding effective international collaboration among the stakeholders (Trouwborst et al., 2017). At the EU level, despite the obligation of EU Member states to implement the environmental directives and the establishment of Natura 2000 network to protect species and habitats of community interest, the conservation measures are hindered as the appropriate management of the sites is still not implemented (Kati et al., 2015; Hermoso et al., 2022). Conservation scientists identified that (a) conservation efforts have been inadequately coordinated within and across the EU Member States, (b) mainstreaming biodiversity conservation in sectoral policy has been suboptimal, and (c) adequate funding and effective enforcement of conservation management have not been in in place (Hermoso et al., 2022). An earlier study reported the lack of political will toward effective implementation, the negative attitude of local stakeholders, the lack of background knowledge of local stakeholders, and the understaffing of Natura 2000 management authorities as main weaknesses (Kati et al., 2015). Therefore, addressing these weaknesses is instrumental in improving the conservation status of protected species and habitats in the EU Member States as well as the neighboring countries.

\section{Recommendations for Improving the Pontocaspian Legal Landscape}

Laws and regulations that list the PC species and/or habitats need to be updated and amended according to the best available scientific knowledge. At the EU-level, the Appendices of the Bern Convention list very few species of aquatic invertebrates and endemic PC species are absent (Figure 3; Supplementary Table 4). Inclusion of threatened PC invertebrate species in the Appendices of Bern Convention, following the Recommendation No. 56 (1997) concerning guidelines to be taken into account while making proposals for amendment of Appendices I and II of the Convention and while adopting amendments, is important. The same applies to amendments of the EU Habitats Directive and Water Framework Directive. Listing PC invertebrate species in Appendices of CITES is perhaps less urgent due to the low commercial and economic value of the PC invertebrate species resulting in low pressure on these taxa from international trade. Similarly, the Convention on Migratory Species shall require no inclusion of PC invertebrate species in its appendices due to limited migration of these taxa. At the Black Sea regional level, the Black Sea Red Data Book (Dumont et al., 1999) requires an urgent update. It is also necessary to update the RDBU (Akimov, 2009) and amend the species list in the Romanian Emergency ordinance No. 57/2007 to adequately incorporate the missing PC invertebrate species in national legal documents.

Pontocaspian species from different taxonomic groups (e.g., Cnidaria, Mollusca, Crustacea) are unevenly represented in different lists and can benefit from consistency in conservation regulations. For example, in the RDBU, Crustacea, Bivalvia, and Cnidaria are relatively well-embodied, but most of the endangered gastropods are absent (Figure 3; Supplementary Table 4). Romanian Government Emergency Ordinance no. 57/2007 lists all three PC limnocardiine bivalve species and one PC gastropod species, but all the other invertebrate groups are missing. IUCN assessments do not include most of the PC invertebrate groups, but only mollusks (Cuttelod et al., 2011) and crayfish Astacus pachypus (listed as Pontastacus pachypus and Data Deficient, in need of an update) are included in the European-level assessments (Figure 3; Supplementary Table 4). Furthermore, most of the legal documents dealing with PC biodiversity conservation are outdated and in need of an update. Recently, a new red list 


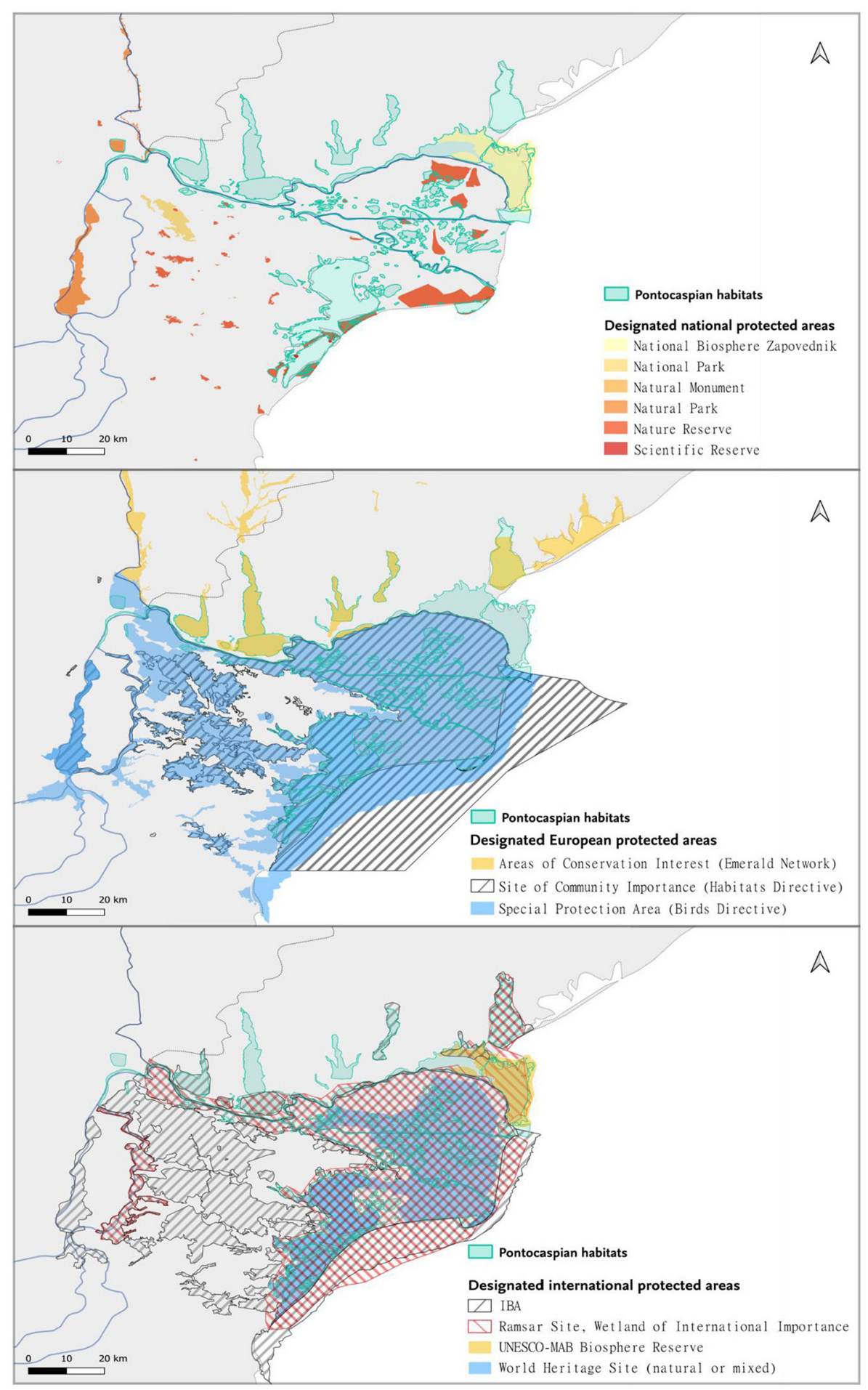

FIGURE 4 | Pontocaspian habitat coverage by protected areas, overlayed by Ramsar sites, UNESCO Biosphere Reserve and World Heritage Sites, Important Bird Areas, Emerald and Natura 2000 network sites, and the national protected areas.

has been approved by the Ministry of Ecology and Natural Resources of Ukraine (Order No. 29 of January 19, 2021 on approval of lists of species of animals listed in RDBU and species of animals excluded from RDBU). The new list included an endangered crayfish Astacus pachypus (Bláha et al., 2017; Policar et al., 2018) and a gastropod Clathrocaspia knipowitchii, which 
were absent from RDBU before. At the same time, species that expanded outside their native range were excluded from the list, for example, Hemimysis anomala and Gmelina pusilla Sars, 1896. Despite the updated list, a new edition of RDBU has not yet been prepared which would map the modern distribution of species, document the population trends and anthropogenic drivers of change, and establish the necessary protection measures. One of the reasons for partial inclusion of PC invertebrate taxa in legal documents may be the lack of a consistent taxonomy, which has made the production of a list of PC invertebrate species virtually impossible till now. Clearly, the taxonomy of PC biota needs to be updated, i.e., the taxonomic synonymies fixed [see Supplementary Table 4, but also Wesselingh et al. (2019) and Gogaladze et al. (2021)], before policymakers can include them in the legal documents.

Selection criteria for inclusion of species in national policy documents and assessments shall be based on best scientific knowledge and transparent criteria in Romania and Ukraine. Unlike the broad-sweep, largely unbiased IUCN approach (e.g., see Böhm et al., 2020), evaluation of species for conservation purposes at the national level in Romania and Ukraine often depends on the availability and interests of experts and conservation organizations. For example, the selection process of taxa for evaluation in the RDBU depends on personal choices of experts, which is then approved by the RDBU commission members as well as the state representatives, rather than on any transparent criteria (MOS, pers. comm). The same applies to Romania (Gogaladze et al., 2020a). Consequently, there is often a bias toward the "preferred species" (species that are well-known or have specialists working on them) resulting in omission of other species from evaluations. This automatically translates to the decisions made on choices of species for inclusion in the regional Black Sea Red Data Book (BSRDB). As a result, some common widespread species are given the status of "vulnerable" or even "endangered" in RDBU and BSRDB (MOS, pers. comm). This trend is universal and not unique to Romania and Ukraine (see Martín-López et al., 2007, 2009).

Revision of Annex I of Resolution 4 (1996) of the Bern Convention (last revised in 2018), to account for the specific salinity conditions of PC habitats, can greatly benefit PC biodiversity conservation. Such a revision shall ideally aim to achieve two major goals, firstly to fully integrate the lowerlevel Danube Delta-specific habitat types from the EUNIS habitat classification into the Bern convention; and secondly to adequately classify the estuarine habitats of non-tidal seas (X01) and brackish coastal lagoons (X03), which are currently not classified in the EUNIS habitat classification and are absent as separate codes in Resolution 4 (1996) of the Bern Convention and Annex I of Habitats Directive. Estuarine habitats of non-tidal seas (X01) and brackish coastal lagoons (X03) are present only as higher-level habitat complexes without distinction between littoral, benthic, and pelagic zones (see Table 1). Providing such detailed classification in the Bern Convention can be expected to result in an updated EUNIS habitat classification and Annex I of the Habitats Directive. The current poor classification of estuarine and lagoonal habitats in the Bern Convention could be understood as a holistic, umbrella approach, which leads to the coverage of all components of the habitat e.g., entire benthic and planktonic communities. However, covering only the large estuarine habitat complex without further detail, the Bern Convention fails to separate the brackish characteristics of PC habitats from "marine" conditions of the estuarine mouth districts (Gogaladze et al., 2021). This is consequential for PC invertebrate community conservation, since human-induced changes in salinity regime as a result of canal constructions and barrier erections that cause a decline of PC species (Varbanov, 2002; Son, 2007b; Trichkova, 2007; van de Velde et al., 2019), are not formally considered as destruction to the biotope. Indicating salinity regimes in estuarine habitats in ecological management programs is paramount, since all large rivers in the region have a controlled artificial regime of flooding and water use, that negatively affects PC biodiversity (Gogaladze et al., 2021). Fresh-water habitats are better classified in the Bern Convention, but there is room for improvement. Specifically, only the thickets of aquatic plants are covered, but benthic and plankton communities are missing, whereas most of the PC communities inhabit mostly bottom substrates.

Revisions and amendments in the current legal documents, that shall be based on best scientific knowledge and transparent criteria, can be expected to improve the legal coherence on both horizontal (between Romania and Ukraine) and vertical (between Romania and EU as well as Ukraine and EU) levels. Legal coherence is an important requirement for effective implementation of conservation policy (Gomar et al., 2014) and an urgent priority in the cross-border conservation context of the Danube Delta. Many species and habitats, including PC biodiversity, cannot be maintained in single and/or isolated PAs due to their dependence on specific interrelationships within their environment. Therefore, the Habitats Directive encourages EU member states, as well as the countries of the Eastern European partnership to ensure the ecological coherence of the Natura 2000 and Emerald Networks. Currently, effective management of Natura 2000 sites in Romania and the Emerald sites in Ukraine is hampered due to administrative challenges in the former (European Commission, 2019) and absence of adequate legislation in the latter (Ministry of Ecology Natural Resources of Ukraine, 2018). However, teams of national and international experts are working hard on addressing these challenges and significant progress has already been made in preparing the Natura 2000 management plans in Romania and drafting new environmental laws and amending the existing laws in Ukraine to improve the biodiversity conservation framework. Such legal framework can be expected to benefit PC biodiversity conservation, as long as PC biodiversity is adequately integrated in legal documents and conservation plans.

\section{Does the Flagship Approach Work Here?}

We did not find studies or reports demonstrating the effectiveness of sturgeon conservation for wider PC taxa. As mentioned in the introduction, flagship species are used to promote public awareness and raise funds for conservation (Verissimo et al., 2011), while the protection of umbrella species is expected to benefit a wide range of co-occurring species (Roberge and Angelstam, 2004; Caro, 2010). To avoid confusing 
the terminology, Caro (2010) coined a term "flagship umbrellas" which refers to those species that integrate both functions. A good example of flagship umbrella species is the giant panda, a well-known flagship species, which was recently documented to also benefit the conservation of co-occurring background species (Li and Pimm, 2016). Sturgeons, along with many freshwater invertebrate species, were identified as species with a potential to be used as flagship umbrellas (Kalinkat et al., 2017). However, Kalinkat et al. (2017) remarked that the list of species they compiled was based on flagship appeal of the taxa and that the umbrella potential for most of them had yet to be tested.

We argue that sturgeon species may not be considered as flagship umbrellas for the PC invertebrate biodiversity. Sturgeons are well-known to the general public, scientific community, and policy makers and considerable funding has been allocated to their conservation from different sources, most notably from the EU LIFE program (https://ec.europa.eu/easme/en/life). However, sturgeon conservation cannot be expected to fully support the protection of PC invertebrate communities because sturgeons are highly mobile and their habitats have a little overlap with the PC habitats within the Danube Delta. Danube sturgeons have been reported to inhabit the Danube River and its three branches (Schmutz and Sendzimir, 2018). Many invertebrate PC species, however have been reported from isolated and/or semi-isolated lakes and ponds in and around the Danube Delta (Figure 1), where sturgeons have not been found. Therefore, sturgeons cannot act as "Pontocaspian pandas" because sturgeonrelated conservation measures and approaches can potentially only benefit the co-occurring invertebrate communities. For cooccurring portion of the PC range, future studies are needed to fully understand the ecological relationships between sturgeons and other PC taxa.

Even if sturgeons as umbrella species cannot provide adequate protection to wider PC biodiversity, the sturgeon conservation networks create an excellent platform for the integration of less-known PC invertebrate biodiversity in the conservation programs. For example, the Program "Sturgeon 2020" aims at halting sturgeon loss and improving their population sizes through (1) acquiring political support for sturgeon conservation; (2) capacity building and law enforcement; (3) insitu sturgeon conservation; (4) ex-situ sturgeon conservation; (5) socio-economic measures in support of sturgeon conservation; and (6) raising public awareness (Sandu, 2013; ICPDR, 2018). Similar measures are urgently required for the invertebrate PC communities and the sturgeon conservation networks can help achieve it if financially supported and incentivized.

Pontocaspian invertebrate species are likely not suitable to act as flagship umbrellas, however, their inclusion in environmental monitoring programs as bioindicators is worth investigating. There are number of studies that have identified and proposed different aquatic invertebrate species as flagship umbrellas as well as bioindicators. For example, Freshwater pearl mussel has been argued to act as an effective flagship umbrella for the conservation of co-occurring biodiversity and an indicator species of healthy river ecosystems (Geist, 2010; Grambow, 2015). In non-permanent aquatic habitats several crayfish species have been proposed as flagship umbrellas and bioindicators, including the Nobel crayfish Astacus astacus (Reynolds and Souty-Grosset, 2011), which belongs to the same genus as the PC crayfish Astacus pachypus. Besides the anthropomorphic features, criteria to "qualify" as a flagship umbrella species include large range size, co-occurring biodiversity, and complex habitat requirements, that overlap those of sympatric species (Kalinkat et al., 2017). Pontocaspian invertebrate species, however, have a patchy distribution in transient and hardly accessible habitats (Gogaladze et al., 2021) and are not well-known to the general public and local conservation organizations (Gogaladze et al., 2020a,b). Therefore, representatives of PC invertebrate fauna are unsuitable to act as flagship umbrellas. On the other hand, PC invertebrate species are good bioindicators as they are highly sensitive to dissolved oxygen levels and salinity, water flow, and sedimentation (Zhadin, 1952; van de Velde et al., 2019; Gogaladze et al., 2021). However, they are not yet part of the environmental monitoring and management programs (this work).

Numerous tools and methods have been developed for bioassessment of aquatic ecosystems in different parts of the world. South Africa has a long history in this field, implementing various freshwater monitoring protocols that could be useful in informing the PC biodiversity conservation (see e.g., Dickens and Graham, 2002; Vorster et al., 2020). These bioassessment techniques are based on combination of scores of different components of aquatic biota. For example, Samways and Taylor (2004) introduced a tool known as the Dragonfly Biotic Index (DBI), which enables assessment of freshwater ecosystems based on the scores of three subindices: geographical distribution, threat status, and habitat sensitivity. The sum of these three scores for all the species found in the assessed sites informs us of the state of the ecosystems. This score was further developed by Vorster et al. (2020) and expanded to continental-scale assessment index. However, implementation of such tools requires IUCN assessments of species conservation status and comprehensive knowledge on the distribution of species. Given the improved knowledge base on PC species identities, distribution and sensitivity, building similar biomonitoring protocol in Romania and Ukraine could assist in integration of PC invertebrate taxa into reporting as well as related legislation.

\section{How Can Pontocaspian Biota Be Better Protected?}

Pontocaspian invertebrate biodiversity conservation requires community-tailored conservation approaches. Literature suggests that Romania and Ukraine meet most of the objectives of conserving globally important biological diversity within the Danube Delta, e.g., the wetlands and bird populations (The World Bank Study Team, 2014). The endemic PC biodiversity, however, is declining and the legal basis to remedy this decline is weak in case of sturgeons (see e.g., ECODIT LLC, 2017; ICPDR, 2018), or non-existent in case of most PC invertebrate groups (this work). While the decline of sturgeon populations is recognized by the $\mathrm{EU}$, the International Commission for the Protection of Danube River (ICPDR) and individual country authorities, the majority of PC invertebrate species are not part of the biodiversity conservation agenda. We 
argue that insufficient legal recognition of invertebrate PC biodiversity is an important driver of their demise, which, in turn, could be due to poor knowledge on PC species identities (Wesselingh et al., 2019) and their distributions (Gogaladze et al., 2021), resulting into low conservation priority and incentive for stakeholders to act (Gogaladze et al., 2020a,b).

Pontocaspian invertebrate species shall be integrated in the PA management plans. National PAs do not cover most of the PC habitats in the Danube Delta (Table 2). Although Natura 2000 and Emerald sites cover most of the PC habitats, these networks only provide protection to species that are listed in the Annexes of Habitats and Birds Directives and the Appendices of the Bern Convention. Pontocaspian invertebrate species are absent from relevant annexes and appendices (see Figure 3; Supplementary Table 4), which means that they are automatically absent from site evaluations and environmental impact assessment studies. Unlike the national PA, on Natura 2000 and Emerald sites practically all types of activities are permitted, provided that they do not cause adverse impact on the species and habitats for which the given site was created. Therefore, PC invertebrate species cannot be adequately protected through the Natura 2000 and Emerald Network sites. Poor classification of PC habitats in Bern Convention (Table 1) could further limit the adequate assessments and site evaluations within these habitats. Additionally, the Emerald Network is relatively new and not yet fully integrated in Ukrainian legislation.

In transnational PAs fragmentation of conservation measures and governance cannot be avoided, however, its adverse effects can be mitigated if innovative measures are used and harmonized across borders. Dallimer and Strange (2015) outlined four pathways for future research that has potential to enhance our ability to address the adverse effects of socio-political borders on conservation, including the importance of demonstrating the benefits of biodiversity and ecosystem services for the material wellbeing of people living either side of socio-political borders and understanding behavior and incentives of local stakeholders, among others. Another study suggests to enhance the adaptive capacity of organizations managing cross-border PA network to buffer both, political influences and ecological pressures to conserve biodiversity (Clement et al., 2016). To improve the implementation of Natura 2000 network, several measures were suggested by Kati et al. (2015), such as increasing public awareness, providing environmental education to local communities, involving high-quality conservation experts, strengthening quality control of environmental impact assessment studies, and establishing a specific Natura 2000 fund.

Taking into account the particularities of our case, we propose a set of seven measures that should be implemented for improving the conservation status of PC invertebrate biodiversity:

(1) Improve the knowledge base on taxonomy, distribution and ecology of PC biodiversity.
(2) Improve the legal basis for PC biodiversity conservation at all levels of governance (see above).

(3) Integrate PC biodiversity in the PA management plans.

(4) Include specific references to PC habitats and species in the environmental impact assessment studies.

(5) Identify and establish a set of PC species as bioindicators of ecosystem health, similar to Dragonfly Biotic Index in rivers.

(6) Enhance cooperation between scientists and NGOs to facilitate joint environmental awareness raising and capacity building activities for local authorities and stakeholders.

(7) Establish a harmonized transnational management plan for the conservation of PC biodiversity and provide adequate funding for its implementation.

\section{CONCLUSIONS}

This study examined the current legal basis for addressing the decline of endemic aquatic biodiversity in Romania and Ukraine, known as PC biota. The study showed that PC habitats and invertebrate species are poorly represented in international and national legal documents, even though they urgently require protection. Even though the PA network covers large parts of PC habitats, management plans are either not in place or fail to address the PC biodiversity conservation, providing incidental and therefore sub-optimal protection to the PC biodiversity. Furthermore, current PC biodiversity related legal landscape is incoherent on both horizontal (between Romania and Ukraine) and vertical (between both countries and EU) levels. Pontocaspian flagship species such as the sturgeons are recognized to be under great threat and are well-represented in legal documents. However, they cannot be considered as optimal umbrella species for the conservation of wider PC taxa due to habitat mismatches. We recommend updating the laws and regulations that list the $\mathrm{PC}$ species and/or habitats and amendments according to the best available scientific knowledge. Pontocaspian invertebrate biodiversity conservation requires integration of this biota in the PA management plans and the development of PC invertebrate community-tailored conservation approaches. Pontocaspian invertebrate species as bioindicators for environmental monitoring and management shall be further explored.

\section{AUTHOR CONTRIBUTIONS}

AG, JB, MS, FW, and NR contributed to conception and design of the study. AG wrote the first draft of the manuscript. JB, MS, OM, CS, CA, SM, and NR wrote sections of the manuscript. ML performed habitat mapping. All authors contributed to manuscript revision, read, and approved the submitted version.

\section{FUNDING}

This research was sponsored by the PRIDE (Pontocaspian RIse and DEmise) project, which received funding from the 
European Union's Horizon 2020 research and innovation programme under the Marie Sklodowska-Curie grant agreement No. 642973.

\section{ACKNOWLEDGMENTS}

We would like to thank the EU Innovative Training Network (ITN) Pontocaspian Biodiversity Rise and Demise (PRIDE) Program (grant agreement number: 642973-PRIDE-H2020MSCAITN-2014) for funding this research. We also thank Ingrid

\section{REFERENCES}

Akimov, I. A. (2009). Red Data Book of Ukraine. Animal World. Kiev: Globalconsulting. [in Ukrainian].

Audzijonyte, A., Daneliya, M. E., Mugue, N., and Väinölä, R. (2008). Phylogeny of Paramysis (Crustacea: Mysida) and the origin of Ponto-Caspian endemic diversity: resolving power from nuclear protein-coding genes. Mol. Phylogenet. Evol. 46, 738-759. doi: 10.1016/j.ympev.2007.11.009

Baboianu, G. (2016). "Danube Delta: The Transboundary Wetlands (Romania and Ukraine)," in The Wetland Book: II: Distribution, Description and Conservation, eds M. Finlayson, G. R. Milton, R. C. Prentice and N. C. Davidson (Cham: Springer), 1-12.

Black Sea Commission (1992). Convention on the Protection of the Black Sea Against Pollution. Bucharest: Black Sea Commission.

Bláha, M., Uzhytchak, M., Bondarenko, V., and Policar, T. (2017). The least known European native crayfish Astacus pachypus (Rathke, 1837) revealed its phylogenetic position. Zool. Anz. 267, 151-154. doi: 10.1016/j.jcz.2017.03.001

Böhm, M., Dewhurst-Richman, N. I., Seddon, M., Ledger, S. E., Albrecht, C., Allen, D., et al. (2020). The conservation status of the world's freshwater molluscs. Hydrobiologia 848, 3231-3254. doi: 10.1007/s10750-020-04385-w

Brandon, L. (2018). pdfsearch: search tools for PDF files. J. Open Source Softw. 3:668. doi: 10.21105/joss.00668

Caro, T. (2010). Conservation by Proxy: Indicator, Umbrella, Keystone, Flagship, and Other Surrogate Species. Washington, DC: Island Press.

CBD (1992). Convention on Biological Diversity. U.N.T.S. Vol. 1760.

CITES (1973). Convention on International Trade in Endangered Species of Wild Fauna and Flora. U.N.T.S. Vol. 1760.

Clement, S., Moore, S. A., and Lockwood, M. (2016). Letting the managers manage: analyzing capacity to conserve biodiversity in a cross-border protected area network. Ecol. Soc. 21:39. doi: 10.5751/ES-08171-210339

CMS (1979). Convention on the Conservation of Migratory Species of Wild Animals. U.N.T.S. Vol. 1651. Bonn: CMS.

Council of Europe (1979). Convention on the Conservation of European Wildlife and Natural Habitats. E.T.S. No. 104. (Bern: Council of Europe). (Bern: Council of Europe). Available online at: https://rm.coe.int/1680078aff

Council of Europe (2018). Convention on the Conservation of European Wildife and Natural Habitats. Recommendation No. 199 of the Standing Committee, adopted on 30 November 2018 on the Pan-European Action Plan for the conservation of the sturgeon. (Strasbourg: Council of Europe). Available online at: https://rm.coe.int/recommendation-199-2018-actionplan-sturgeon/1680a01895

Cuttelod, A., Seddon, M., and Neubert, E. (2011). European Red List of Non-marine Molluscs. Publications Office of the European Union Luxembourg.

Dallimer, M., and Strange, N. (2015). Why socio-political borders and boundaries matter in conservation. Trends Ecol. Evol. 30, 132-139. doi: 10.1016/j.tree.2014.12.004

De Klemm, C., and Shine, C. (1993). Biological Diversity Conservation and the Law: Legal Mechanisms for Conserving Species and Ecosystems. IUCN.

Delreux, T., and Happaerts, S. (2016). Environmental Policy and Politics in the European Union. Macmillan International Higher Education.

Díaz, C. L. (2010). The Bern Convention: 30 years of nature conservation in Europe. Rev. Eur. Commun. Int. Environ. Law 19, 185-196. doi: $10.1111 /$ j.1467-9388.2010.00676.x
Visseren-Hamakers from Radboud University Nijmegen, for her guidance and advices on researching the Pontocaspian policy landscape. Finally, we thank our reviewers who gave us invaluable comments that improved our work considerably.

\section{SUPPLEMENTARY MATERIAL}

The Supplementary Material for this article can be found online at: https://figshare.com/articles/journal_contribution/ Pontocaspian_Biodiversity_Conservation_Policy/18637238.

Díaz, S., Settele, J., Brondízio, E., Ngo, H., Guèze, M., Agard, J., et al. (2019). Summary for policymakers of the Global Assessment Report on Biodiversity and Ecosystem Services of the Intergovernmental Science-Policy Platform on Biodiversity and Ecosystem Services. Bonn, Germany.

Dickens, C. W., and Graham, P. (2002). The South African Scoring System (SASS) version 5 rapid bioassessment method for rivers. Afric. J. Aquat. Sci. 27, 1-10. doi: $10.2989 / 16085914.2002 .9626569$

DRPC (1994). Convention on Cooperation for the Protection and Sustainable Use of the River Danube. OJ L342, p. 19.

Dumont, H., Mamaev, V., and Zaitsev, Y. (1999). Black Sea Red Data Book. United Nations Office for Project Services 413.

ECODIT LLC (2017). Ukraine Biodiversity Analysis. Arlington, TX: United States Agency for International Development.

EU (1992). Council Directive 92/43/EEC of 21 May 1992 on the Conservation of Natural Habitats and of Wild Fauna and Flora. O.J.O.T.E. Union.

EU (1996). Council Regulation (EC) No 338/97 of 9 December 1996 on the Protection of Species of Wild Fauna and Flora by Regulating Trade Therein.

EU (2000). Directive 2000/60/EC of the European Parliament and of the Council of 23 October 2000 Establishing a Framework for Community Action in the Field of Water Policy. O.J.O.T.E. Union.

EU (2008). Directive 2008/56/EC of the European Parliament and of the Council of 17 June 2008 Establishing a Framework for Community Action in the Field of Marine Environmental Policy. O.J.O.T.E. Union.

EU (2009). Directive 2009/147/EC of the European Parliament and of the Council of 30 November 2009 on the conservation of wild birds. O.J.O.T.E. Union.

European Commission (2019). The EU Environmental Implementation Review 2019, Country Report - Romania. Brussels.

Evans, D. (2012). Building the European Union's Natura 2000 network. Nat. Conserv. 1:11. doi: 10.3897/natureconservation.1.1808

Favreau, J. M., Drew, C. A., Hess, G. R., Rubino, M. J., Koch, F. H., and Eschelbach, K. A. (2006). Recommendations for assessing the effectiveness of surrogate species approaches. Biodivers. Conserv. 15, 3949-3969. doi: 10.1007/s10531-005-2631-1

Freyhof, J., and Brooks, E. (2011). European Red List of Freshwater Fishes. Publications Office of the European Union, Luxembourg.

Geist, J. (2010). Strategies for the conservation of endangered freshwater pearl mussels (Margaritifera margaritifera L.): a synthesis of conservation genetics and ecology. Hydrobiologia 644, 69-88. doi: 10.1007/s10750-010-0190-2

Giosan, L., Bokuniewicz, H., Panin, N., and Postolache, I. (1999). Longshore sediment transport pattern along the Romanian Danube delta coast. J. Coast. Res. 15, 859-871.

Glowka, L., Shine, C., Santos, O. R., Phāruka, M., and Gündling, L. (1998). A Guide to Undertaking Biodiversity Legal and Institutional Profiles. IUCN-The World Conservation Union.

Gogaladze, A., Raes, N., Biesmeijer, J. C., Ionescu, C., Pavel, A.-B., Son, M. O., et al. (2020a). Social network analysis and the implications for Pontocaspian biodiversity conservation in Romania and Ukraine: a comparative study. PLoS ONE 15:e0221833. doi: 10.10.1371/journal.pone.0221833

Gogaladze, A., Son, M. O., Lattuada, M., Anistratenko, V. V., Syomin, V. L., pavel, A. B., et al. (2021). Decline of unique Pontocaspian biodiversity in the Black Sea Basin: a review. Ecol. Evol. 11, 12923-12947. doi: 10.1002/ece3.8022

Gogaladze, A., Wesselingh, F. P., Biesmeijer, K., Anistratenko, V., Gozak, N., Son, M. O., et al. (2020b). Using social network 
analysis to assess the Pontocaspian biodiversity conservation capacity in Ukraine. Ecol. Soc. 25:25. doi: 10.5751/ES-11575-25 0225

Gomar, J. O. V., Stringer, L. C., and Paavola, J. (2014). Regime complexes and national policy coherence: experiences in the biodiversity cluster. Glob. Govern. 20, 119-145. doi: 10.5555/1075-2846-20.1.119

Grambow, M. G. (2015). Experiences from the International Rhine Water Management. Strat. Anal. 39, 9-15. doi: 10.1080/09700161.2014.98 0540

Grigorovich, I. A., Therriault, T. W., and MacIsaac, H. J. (2003). "History of aquatic invertebrate invasions in the Caspian Sea," in Marine Bioinvasions: Patterns, Processes and Perspectives, ed J. Pederson (Dordrecht: Springer), 103-115.

Groves, C., Valutis, L., Vosick, D., Neely, B., Wheaton, K., Touval, J., et al. (2000). Designing a Geography of Hope: A Practitioner's Handbook for Ecoregional Conservation Planning. Vols. 1, 2. The Nature Conservancy, Virginia (EUA).

Gubbay, S., Sanders, N., Haynes, T., Janssen, J., Rodwell, J., Nieto, A., et al. (2016). European Red List of Habitats, Part 1: Marine Habitats. European Union.

Hermoso, V., Carvalho, S., Giakoumi, S., Goldsborough, D., Katsanevakis, S., Leontiou, S., et al. (2022). The EU biodiversity strategy for 2030: opportunities and challenges on the path towards biodiversity recovery. Environ. Sci. Policy 127, 263-271. doi: 10.1016/j.envsci.2021.10.028

ICPDR (2015). The Danube River Basin District Management Plan. ICPDRInternet. Commission for the Protection of the Danube River Secretariat.

ICPDR (2018). Sturgeon Strategy.

ICPDR (2021). Danube River Basin Management Plan. Part A - Basin-Wide Overview Update. CPDR - International Commission for the Protection of the Danube River.

Iwanski, T. (2011). Ukraine-Romania: A Sustained Deadlock. OSW Centre for Eastern Studies 30.

Janssen, J., Rodwell, J., and Criado, M. (2016). European Red List of Habitats, Part 2: Terrestrial and Freshwater Habitats. European Union.

Jeroen, O. (2021). pdftools: Text Extraction, Rendering and Converting of PDF Documents. $R$ package version 3.0.1. Available online at: https://CRAN.Rproject.org/package $=$ pdftools

Kalinkat, G., Cabral, J. S., Darwall, W., Ficetola, G. F., Fisher, J. L., Giling, D. P., et al. (2017). Flagship umbrella species needed for the conservation of overlooked aquatic biodiversity. Conserv. Biol. 31, 481-485. doi: $10.1111 /$ cobi.12813

Kark, S., Tulloch, A., Gordon, A., Mazor, T., Bunnefeld, N., and Levin, N. (2015). Cross-boundary collaboration: key to the conservation puzzle. Curr. Opin. Environ. Sustain. 12, 12-24. doi: 10.1016/j.cosust.2014.08.005

Kati, V., Hovardas, T., Dieterich, M., Ibisch, P. L., Mihok, B., and Selva, N. (2015). The challenge of implementing the European network of protected areas Natura 2000. Conserv. Biol. 29, 260-270. doi: 10.1111/cobi. 12366

Koester, V. (2002). The five global biodiversity-related conventions: a stocktaking. Rev. Eur. Comp. and Int'l Envtl. L. 11:96.

Landman, T. (2002). Issues and Methods in Comparative Politics: An Introduction. London: Routledge.

Li, B. V., and Pimm, S. L. (2016). China's endemic vertebrates sheltering under the protective umbrella of the giant panda. Conserv. Biol. 30, 329-339. doi: $10.1111 /$ cobi.12618

López-Hoffman, L., Varady, R. G., Flessa, K. W., and Balvanera, P. (2010). Ecosystem services across borders: a framework for transboundary conservation policy. Front. Ecol. Environ. 8, 84-91. doi: 10.1890/070216

Marret, F., Leroy, S., Chalié, F., and Françoise, F. (2004). New organic-walled dinoflagellate cysts from recent sediments of Central Asian seas. Rev. Palaeobot. Palynol. 129, 1-20. doi: 10.1016/j.revpalbo.2003.10.002

Martín-López, B., Montes, C., and Benayas, J. (2007). The non-economic motives behind the willingness to pay for biodiversity conservation. Biol. Conserv. 139, 67-82. doi: 10.1016/j.biocon.2007.06.005

Martín-López, B., Montes, C., Ramírez, L., and Benayas, J. (2009). What drives policy decision-making related to species conservation? Biol. Conserv. 142, 1370-1380. doi: 10.1016/j.biocon.2009.01.030

Ministry of Ecology and Natural Resources of Ukraine (2015). Fifth National Report of Ukraine to the Convention on Biological Diversity.
Ministry of Ecology and Natural Resources of Ukraine (2018). Sixth National Report of Ukraine on the Implementation of the Convention on Biological Diversity. Kiev.

Ministry of Environment and Climate Change of Romania (2014). Fifth National Report of Romania to the Convention on Biological Diversity.

Monchenko, V. I. (2003). Free-Living Cyclopoid Copepods of Ponto-Caspian Basin. Kiev: Naukova dumka, 1-350. [in Russian].

Mordukhay-Boltovskoy, F. (1960). Kaspiyskaya Fauna v Azovo-Chernomorskom Basseyne. Izdatel'stvo Akademii Nauk SSSR, Leningrad, 228. [in Russian].

Munteanu, A., Ehlinger, T., Golumbeanu, M., and Tofan, L. (2013). Network environmental governance in the $\mathrm{EU}$ as a framework for trans-boundary sturgeon protection and cross-border sustainable management. J. Environ. Protect. Ecol. 14, 685-692.

OECD (2019). Biodiversity: Finance and the Economic and Business Case for Action. Report prepared for the G7 Environment Ministers' Meeting, 5-6 May 2019. Available online at: https://www.oecd.org/environment/resources/biodiversity/ G7-report-Biodiversity-Finance- and-the-Economic-and-Business-Case-forAction.pdf

Policar, T., Bondarenko, V., Bezusyj, O., Stejskal, V., Kristan, J., Malinovskyi, O., et al. (2018). Crayfish in central and southern Ukraine with special focus on populations of indigenous crayfish Astacus pachypus (Rathke, 1837) and their conservation needs. Aquat. Conserv. Mar. Freshwater Ecosyst. 28, 6-16. doi: $10.1002 /$ aqc. 2798

Popa, O. P., Sarkany-Kiss, A., Kelemen, B. S., Iorgu, E. I., Murariu, D., and Popa, L. O. (2009). Contributions to the knowledge of the present Limnocardiidae fauna (Mollusca: Bivalvia) from Romania. Trav. Mus. Natl. Hist. Natur. 'Grig. Ant. 52, 7-15.

Reinartz, R., Bloesch, J., Sandu, C., Suciu, R., Lenhardt, M., Guti, G., et al. (2012). "Sturgeon conservation in the Danube River Basin: how to implement the Sturgeon Action Plan 2005," in Proc. 39. IAD Conf. (Szentendre), 21-24.

Reynolds, J., and Souty-Grosset, C. (2011). Management of Freshwater Biodiversity: Crayfish as Bioindicators. New York: Cambridge University Press.

Rinker, T. W. (2021). textreadr: Read Text Documents into $R$ version 1.2.0. Buffalo, NY. Available online at: https://github.com/trinker/textreadr

Roberge, J. M., and Angelstam, P. (2004). Usefulness of the umbrella species concept as a conservation tool. Conserv. Biol. 18, 76-85. doi: 10.1111/j.1523-1739.2004.00450.x

Samways, M. J., and Taylor, S. (2004). Impacts of invasive alien plants on RedListed South African dragonflies (Odonata): working for water. S. Afr. J. Sci. $100,78-80$.

Sandu, C., Reinartz, R., and Bloesch, J. (eds.). (2013). "Sturgeon 2020": A Program for the Protection and Rehabilitation of Danube Sturgeons. Danube Sturgeon Task Force (DSTF) and EU Strategy for the Danube River (EUSDR) Priority Area (PA),

Schmutz, S., and Sendzimir, J. (2018). Riverine Ecosystem Management: Science for Governing Towards a Sustainable Future. Cham: Springer Nature.

Singh, J. (1999). Study on the Development of Transboundary Natural Resource Management Areas in Southern Africa: Global Review; Lessons Learned. Biodiversity Support Program, Washington, DC (EUA).

Skjærseth, J. B., and Wettestad, J. (2002). Understanding the effectiveness of EU environmental policy: how can regime analysis contribute? Env. Polit. 11, 99-120. doi: 10.1080/714000635

Son, M. O. (2007a). Invasive Molluscs in Fresh and Brackish Waters of the Northern Black Sea Region. Odessa: Druk. p. 1-131.

Son, M. O. (2007b). Native range of the zebra mussel and quagga mussel and new data on their invasions within the Ponto-Caspian Region. Aquat. Invas. 2, 174-184. doi: 10.3391/ai.2007.2.3.4

Teampau, P. (2020). Trouble in paradise: competing discourses and complex governance in the Romanian danube delta. Mar. Pol. 112:103522. doi: 10.1016/j.marpol.2019.103522

The Government of Romania (2014). National Strategy and Action Plan for Biodiversity Conservation, Romania.

The World Bank Study Team (2014). Draft Danube Delta Integrated Sustainable Development Strategy (2030). Report 2.2.

The World Bank Study Team (2015). Report on Strategic Environmental Assessment in Danube Delta. 
Trichkova, T. (2007). "Zoobenthos of non-lotic Bulgarian wetlands", in Inventory of Bulgarian Wetlands and their Biodiversity. Part 1: Non-Lotic Wetlands, eds T. Michev and M. Stoyneva (Sofia: Publishing House Elsi-M), 185-195.

Trouwborst, A., Blackmore, A., Boitani, L., Bowman, M., Caddell, R., Chapron, G., et al. (2017). International wildlife law: understanding and enhancing its role in conservation. Bioscience 67, 784-790. doi: 10.1093/biosci/bix,086

UNECE (1991). Convention on Environmental Impact Assessment in a Transboundary Context. U.N.T.S. Vol. 1989. Geneva: UNECE.

UNESCO (1971). Convention on Wetlands of International Importance Especially as Waterfowl Habitat. U.N.T.S. Vol. 996. (Ramsar: UNESCO). Available online at: https://treaties.un.org/doc/Publication/UNTS/Volume\%20996/volume996-I- 14583-English.pdf

UNESCO (1972). Convention for the Protection of the World Cultural and Natural Heritage. U.N.T.S. Vol. 1037.

van de Velde, S., Jorissen, E. L., Neubauer, T. A., Radan, S., Pavel, A. B., Stoica, M., et al. (2019). A conservation palaeobiological approach to assess faunal response of threatened biota under natural and anthropogenic environmental change. Biogeosciences 16, 2423-2442. doi: 10.5194/bg-16-2423-2019

Varbanov, M. (2002). "Lakes and marshes," in Geography of Bulgaria. Physical Geography. Socio-Economic Geography, eds I. Kopralev, M. Yordanova, and C. Mladenov (Sofia: ForCom Publishing House), 237-242.

Verissimo, D., MacMillan, D. C., and Smith, R. J. (2011). Toward a systematic approach for identifying conservation flagships. Conserv. Lett. 4, 1-8. doi: 10.1111/j.1755-263X.2010.00151.x

Visseren-Hamakers, I. J. (2015). Integrative environmental governance: enhancing governance in the era of synergies. Curr. Opin. Environ. Sustain. 14, 136-143. doi: 10.1016/j.cosust.2015.05.008

Visseren-Hamakers, I. J. (2018). Integrative Governance: The Relationships Between Governance Instruments Taking Center Stage. London: SAGE Publications.

Vorster, C., Samways, M. J., Simaika, J. P., Kipping, J., Clausnitzer, V., Suhling, F., et al. (2020). Development of a new continental-scale index for freshwater assessment based on dragonfly assemblages. Ecol. Indic. 109:105819. doi: 10.1016/j.ecolind.2019.105819
Wesselingh, F. P., Neubauer, T. A., Anistratenko, V. V., Vinarski, M. V., Yanina, T., ter Poorten, J. J., et al. (2019). Mollusc species from the Pontocaspian region - an expert opinion list. Zookeys 827, 31-124. doi: 10.3897/zookeys.827.31365

Wickham et al. (2019). Welcome to the tidyverse. J. Open Source Softw. 4:1686. doi: 10.21105 /joss. 01686

World Economic Forum (2020). The Global Risks Report.

WWF (2007). Danube Delta: A Natural Gateway to Europe Ecology and Economy in Harmony. D-CP (ed). Vienna: WWF International.

Zenkevitch, L. (1963). Biology of the Seas of the USSR. New York, NY: Interscience Publishers.

Zhadin, V. (1952). Mollyuski Presnykh $i$ Solonovatykh vod SSSR. Izdatel'stvo Akademii Nauk SSSR. Moskva: Leningrad. p. 376 .

Conflict of Interest: The authors declare that the research was conducted in the absence of any commercial or financial relationships that could be construed as a potential conflict of interest.

Publisher's Note: All claims expressed in this article are solely those of the authors and do not necessarily represent those of their affiliated organizations, or those of the publisher, the editors and the reviewers. Any product that may be evaluated in this article, or claim that may be made by its manufacturer, is not guaranteed or endorsed by the publisher.

Copyright $\odot 2022$ Gogaladze, Biesmeijer, Son, Marushchak, Wesselingh, Lattuada, Sandu, Albrecht, Mihailescu and Raes. This is an open-access article distributed under the terms of the Creative Commons Attribution License (CC BY). The use, distribution or reproduction in other forums is permitted, provided the original author(s) and the copyright owner(s) are credited and that the original publication in this journal is cited, in accordance with accepted academic practice. No use, distribution or reproduction is permitted which does not comply with these terms. 